\title{
16S rRNA GENE-BASED IDENTIFICATION OF BACTERIA IN POSTOPERATIVE ENDOPHTHALMITIS BY PCR- DENATURING GRADIENT GEL ELECTROPHORESIS (PCR-DGGE) FINGERPRINTING
}

\author{
Yendi Navarro-Noya ${ }^{1}$, César Hernández-Rodríguez ${ }^{1}$, Juan C. Zenteno ${ }^{3,4}$, Beatriz Buentello-Volante ${ }^{3}$, Mario E. Cancino- \\ Díaz $^{2}$, Janet Jan-Roblero ${ }^{1}$, Juan C.Cancino-Díaz ${ }^{{ }^{*}}$
}

${ }^{1}$ Departamento de Microbiología, Escuela Nacional de Ciencias Biológicas-IPN, Mexico, D.F. Mexico; ${ }^{2}$ Departamento de Inmunología, Escuela Nacional de Ciencias Biológicas-IPN, Mexico, D.F. Mexico. ${ }^{3}$ Instituto de Oftalmología Fundación Conde de Valenciana, Mexico, D.F. Mexico; ${ }^{4}$ Departamento de Bioquímica, Facultad de Medicina, UNAM, Mexico, D.F., Mexico.

Submitted: January 24, 2011; Approved: August 30, 2011.

\begin{abstract}
Conventional microbiological culture techniques are frequently insufficient to confirm endophthalmitis clinical cases which could require urgent medical attention because it could lead to permanent vision loss. We are proposing PCR-DGGE and 16S rRNA gene libraries as an alternative to improve the detection and identification rate of bacterial species from endophthalmitis cases.
\end{abstract}

Key words: endophthalmitis, Staphylococcus epidermidis, PCR, DGGE.

Microbiological endophthalmitis diagnosis is performed routinely by conventional microbiological culture techniques (CMCT) and microscopic examination of vitreous and aqueous humors. However, the sensitivity of bacterial detection from aqueous and vitreous humor using CMCT is low, ranging from $25 \%$ to $56 \%$ of cases $(2,4,17)$. The low sensitivity of CMCT is due to various factors such as small quantity of specimen, fixation of microorganisms to solid surfaces (intraocular lens, lens fragments, capsule) and consequent decrease of cells in the vitreous/aqueous humor, use of antibiotics before the collection of clinical material and the presence of fastidious microorganisms such as agents causing endophthalmitis (17). The application of PCR-based molecular techniques increases significantly the cases of confirmed endophthalmitis and has prompted their growing utilization in this setting (3). PCRDenaturing Gradient Gel Electrophoresis (PCR-DGGE) is a sensitive technique based on differential melting and separation of similar-sized PCR-amplicons in a linear urea-formamide gradient (15). PCR-DGGE has been employed as an alternative for bacteria detection in conjunctival samples $(22,23)$, however, to our knowledge, this procedure has not been applied in vitreous samples from suspected endophthalmitis cases. Due to the high incidence of cases not detected by CMCT in vitreous samples, which require urgent medical attention since it could lead to vision loss, in this study we used a procedure based on PCR-DGGE in order to solve this problem.

The vitreous samples of 24 patients with postoperative endophthalmitis were obtained mainly by vitrectomy. All vitreous samples were previously analyzed by CMCT and there was no bacterial growth. This study was approved by the ethics review board from our institution, and patients was agreed

\footnotetext{
*Corresponding Author. Mailing address: Prol. de Carpio y Plan de Ayala S/N, Col. Santo Tomás. Delegación Miguel Hidalgo. 11340 Mexico City, Mexico.; Tel.: +52 (55) 5729 6300.; E-mail: jccancinodiaz@hotmail.com
} 
with their participation in the study. Total vitreous DNAs were extracted from $20 \mu \mathrm{L}$ of vitreous sample using DNeasy Tissue kit (Qiagen, CA, USA). The DNA extracted was used as template to amplify the V3 hypervariable region of the bacterial $16 \mathrm{~S}$ rRNA gene by PCR according to Muyzer et al. (15). The PCR products were analyzed using a DCode mutation detection system, following the procedure described by the manufacturer (Bio-Rad Laboratories, Hercules, CA). Twenty $\mu \mathrm{L}$ of PCR samples were applied to $8 \%(\mathrm{w} / \mathrm{v})$ polyacrylamide gels prepared in $1 \mathrm{x}$ TAE buffer. The denaturing gradients contained 40-60\% denaturant [100\% denaturant corresponds to $7 \mathrm{M}$ urea and $40 \%$ (w/v) formamide]. Electrophoresis was performed at $85 \mathrm{~V}$ and $60^{\circ} \mathrm{C}$ during $16 \mathrm{~h}$. DGGE gels were fixed and DNA bands were visualized by silver staining.

DNAs corresponding to 17 vitreous samples from a total of 24 , exhibited the expected fragment size of $16 \mathrm{~S}$ rRNA gene (1500 base pairs), which indicated the presence of bacterial infection. The 7 PCR-negative samples may be explained by fungal infections. The 17 vitreous samples with bacterial infection showed a total of 8 different PCR-DGGE electrophoretic profiles (Figure 1), but only one sample was similar to S. epidermidis ATCC12228 and S. epidermidis skincommensal strain profiles, utilized as controls (profile I, Figure 1). All lanes of the DGGE exhibited more than one band, some samples displaying up to 6 bands, suggesting the presence of at least 6 different bacteria present in such vitreous sample (Figure 1). For this reason, to explore the bacterial diversity associated with vitreous samples, eight 16S rRNA libraries were constructed for each DGGE representative profile according to Navarro-Noya et al. (16). A very low abundance of species was observed and only two species were demonstrated (Table 1). In five of the ribosomal gene libraries (corresponding to the DGGE-profiles II, III, V, VII and VIII) only Streptococcus pneumoniae was detected. In the three remaining libraries (DGGE-profiles I, IV and VI), $S$. epidermidis was the single detected microorganism (Table 1).
The finding of a single bacterial species in each vitreous sample was unexpected, taking into account that several bands were observed in the PCR-DGGE. Furthermore, different PCRDGGE profiles were obtained for S. epidermidis, suggesting that they are different strains of the same bacterial species. The same phenomenon occurred with $S$. pneumoniae. Similar results have been reported regarding the visualization of several bands on a DGGE gel, instead of a single band representative of particular species $(6,24)$. This result can be explained by the intraspecies heterogeneity displayed in a DGGE banding pattern as the result of multiple copies of the ribosomal genes and by the fact that the gene copies have evolved differently $(6,24)$. In order to provide a solution to that issue, some authors had successfully used the $\operatorname{rpoB}$ gene, encoding the beta subunit of RNA polymerase which exists in a single copy within the chromosome $(6,19)$. Also, PCR-DGGE in combination with specific PCR primers has been used for targeting the housekeeping gene glucose kinase, gki, to discriminate between different Streptococcus mitis strains (25). Another explanation for intraspecies heterogeneity could be that $S$. pneumoniae (18) and S. epidermidis (14) are considered microorganisms with a high level of genetic diversity.

In order to determine whether $S$. epidermidis detected in the vitreous samples was commensal or opportunist pathogen, we investigated the presence of some virulence factors associated to this bacterium. First, we confirmed the presence of $S$. epidermidis using two pairs of species-specific oligonucleotides, se705 sequence (11) and parC gene (1). The expected size PCR products were obtained from five vitreous samples and from two control strains (Table 1). Similarly, two additional genes associated with virulence factors (icaA (8) and mecA (10) genes) were amplified in the same fives vitreous samples but not in two control strains (Table 1). The icaA gene participates in biofilm development, one important factor in pathogenesis of this bacterium, while mecA gene is involved in resistance to methicillin antibiotic. Our results were similar to the reported by previous works, which have detected 
virulence factor genes in S. epidermidis strains isolated from clinical cases but not in commensal strains $(8,10,12)$.

$S$. pneumoniae is an alpha hemolytic Gram-positive bacterium, which rarely cause endophthalmitis, in contrast to $S$. epidermidis, a commonly isolated microorganism in cases of endophthalmitis (5). Although endophthalmitis caused by $S$. pneumoniae is infrequent, it has been shown to be more aggressive and associated to a more significant visual impact than caused by S. epidermidis (13). In rabbit endophthalmitis models it has been shown that the polysaccharide capsule (21) and pneumolysin hemolytic activity (20) are important virulence factors for $S$. pneumoniae, whereas S. epidermidis participate in the biofilm production. The diagnostic of endophthalmitis caused by S. pneumoniae is mainly by CMCT and so far, only one study has employed specific-primers PCR for its identification in vitreous samples (9). However, in endophthalmitis caused by $S$. epidermidis other molecular methods for its identification as real-time PCR, (2), FAFLP(7), PCR-RFLP(17), have been used, but not PCR-DGGE as we did here; furthermore, these methods have proven to be more efficient than CMCT $(2,7,17)$.

In this work, PCR-DGGE was applied in order to solve cases where CMCT were not able to infer bacterial presence in vitreous samples. The results presented here demonstrated that the 16S rRNA gene libraries and the profiles exhibited through PCR-DGGE are methods that could identify bacterial strains and displayed the intraspecies variation in both strains of $S$. epidermidis and S. pneumoniae. Furthermore, these results suggest that $S$. epidermidis infectious strains isolated from endophthalmitis were not of commensal origin.

Table 1. Classification of vitreous samples associated with bacterial infection.

\begin{tabular}{|c|c|c|c|c|c|c|}
\hline DGGE profile & Sample $^{\mathrm{a}}$ & Se705 ${ }^{\mathrm{b}}$ Sequence & par $C^{\mathrm{c}}$ gene & $i c a A^{\mathrm{d}}$ gene & $m e c A^{\mathrm{e}}$ gene & Bacterial identification $^{\mathrm{f}}$ \\
\hline \multirow[t]{2}{*}{$\mathrm{I}$} & $\begin{array}{l}\text { Se-A, } \\
\text { Se-S }\end{array}$ & + & + & - & - & Staphylococcus epidermidis \\
\hline & 20 & + & + & + & + & Staphylococcus epidermidis \\
\hline II & $4 \mathrm{~A}, 10,35$ & - & - & - & - & Streptococcus pneumoniae \\
\hline III & $4 \mathrm{~B}$ & - & - & - & - & Streptococcus pneumoniae \\
\hline IV & 9 & + & + & + & + & Staphylococcus epidermidis \\
\hline $\mathrm{V}$ & 11,34 & - & - & - & - & Streptococcus pneumoniae \\
\hline VI & $13,14,15$ & + & + & + & + & Staphylococcus epidermidis \\
\hline VII & 16,39 & - & - & - & - & Streptococcus pneumoniae \\
\hline VIII & $17,21,33,36$ & - & - & - & - & Streptococcus pneumoniae \\
\hline
\end{tabular}

${ }^{a}$ DNA of vitreous samples grouped according with their PCR-DGGE profiles. Se-A corresponded to Staphylococcus epidermidis ATCC12228 and Se-S to Staphylococcus epidermidis skin-commensal strain. ${ }^{\mathrm{b}}$ Specific sequence to Staphylococccus epidermidis (7). ${ }^{\mathrm{c}}$ Gene encoding DNA topoisomerase IV and involved in fluoroquinolones resistance. ${ }^{\mathrm{d}}$ Gene involved in biofilm formation in Staphylococcus epidermidis. ${ }^{\mathrm{e}}$ Gene involved in methicillin resistance in Staphylococcus spp. ${ }^{\mathrm{f}}$ The bacterial identification was based on the sequencing of the clones from the libraries to reach rarefaction curves. +, - Indicate that the PCR product was obtained or not, respectively.

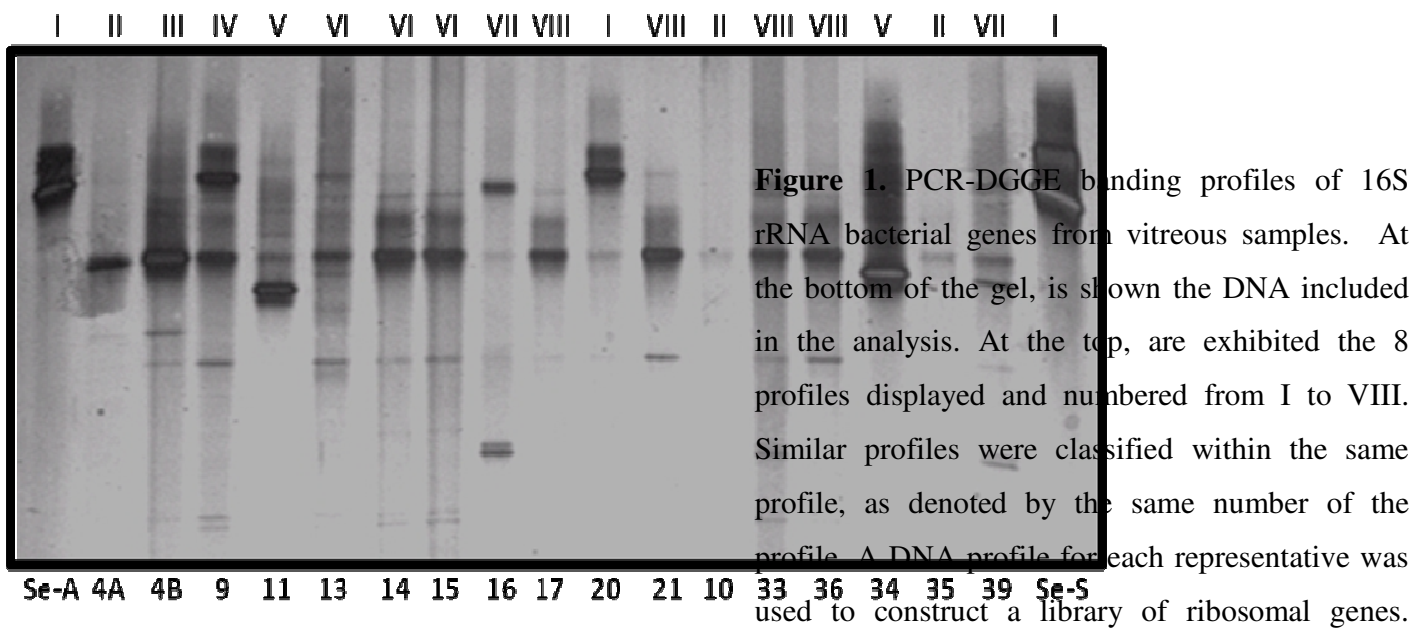

Besides, the PCR-DGGE profiles of $S$. epidermidis, strain ATCC12228 (Se-A; first lane) and strain 


\section{ACKNOWLEDGEMENTS}

JCCD, MCD, CHR and JJR appreciate the scholarships of COFAA and EDI-IPN and SNI-CONACyT.

\section{REFERENCES}

1. Betanzos-Cabrera, G.; Juárez-Verdayes, M.A.; González-González, G.; Cancino-Díaz, M.E.; Cancino-Díaz, J.C. (2009). Gatifloxacin, moxifloxacin, and balofloxacin resistance due to mutations in the gyrA and parC genes of Staphylococcus epidermidis strains isolated from patients with endophthalmitis, corneal ulcers and conjunctivitis. Ophthalmic Res. 42 (1), 43-48

2. Bispo, P.J.; de Melo, G.B.; Hofling-Lima, A.L.; Pignatari, A.C. (2011) Detection and gram discrimination of bacterial pathogens from aqueous and vitreous humor using real-time PCR assays. Invest. Ophthalmol. Vis. Sci. 52 (2), 873-881.

3. Bispo, P.J.; Höfling-Lima, A.L.; Pignatari, A.C. (2009). Molecular biology applied to the laboratory diagnosis of bacterial endophthalmitis. Arq. Bras. Oftalmol. 72 (5), 734-740.

4. Bispo, P.J.M.; Melo, G.B.; d'Azevedo, P.A.; Höfling-Lima, A.L.; Yu, M.C.Z.; Pignatari, A,C. (2008). Endoftalmites bacterianas com culturas positivas: uma revisão de 6 anos. Arq. Bras. Oftalmolol. 71 (5), 617-622.

5. Callegan, M.C.; Gilmore, M.S.; Gregory, M.; Ramadan, R.T.; Wiskur, B.J.; Moyer, A.L.; Hunt, J.J.; Novosad, B.D. (2007). Bacterial endophthalmitis: therapeutic challenges and host-pathogen interactions. Prog. Retin Eye Res. 26 (2), 189-203.

6. Dahllöf, I.; Baillie, H.; Kjelleberg, S. (2000). rpoB-based microbial community analysis avoids limitations inherent in 16S rRNA gene intraspecies heterogeneity. Appl. Environ. Microbiol. 66 (8), 3376-3380.

7. Duggirala, A.; Kenchappa, P.; Sharma, S.; Peeters, J.K.; Ahmed, N.; Garg, P.; Das, T.; Hasnain, S.E. (2007). High-resolution genome profiling differentiated Staphylococcus epidermidis isolated from patients with ocular infections and normal individuals. Invest. Ophthalmol. Vis. Sci. 48 (7), 3239-3245.

8. Gad, G.F.; El-Feky, M.A.; El-Rehewy, M.S.; Hassan, M.A.; Abolella, H.; El-Baky, R.M. (2009). Detection of icaA, icaD genes and biofilm production by Staphylococcus aureus and Staphylococcus epidermidis isolated from urinary tract catheterized patients. J. Infect. Dev. Ctries. 3 (5), 342-351.

9. Guan, H.J.; Lu, H. (2004). Rapid pathogens diagnosis of infected keratitis and endophthalmitis using two steps polymerase chain reaction. Zhonghua Yan Ke Za Zhi. 40 (12), 819-823.

10. Kaplan, S.; Marlowe, E.M.; Hogan, J.J.; Doymaz, M.; Bruckner, D.A.; Simor, A.E. (2005). Sensitivity and specificity of a rapid rRNA gene probe assay for simultaneous identification of Staphylococcus aureus and detection of mecA. J. Clin. Microbiol. 43 (7), 3438-3442.

11. Martineau, F.; Picard, F.J.; Roy, P.H.; Ouellette, M.; Bergeron, M.G. (1996). Species-Specific and ubiquitous DNA-based assays for rapid identification of Staphylococcus epidermidis. J. Clin. Microbiol. 34 (12), 2888-2893.

12. Michelim, L.; Lahude, M.; Araújo, P.R.; Giovanaz, D.S.H.; Müller, G.; Delamare, A.P.L.; Pinto da Costa, S.O.; Echeverrigaray, S. (2005). Pathogenic factors and antimicrobial resistance of Staphylococcus epidermidis associated with nosocomial infections occurring in intensive care units. Braz. J. Microbiol. 36(1).

13. Miller, J.J.; Scott, I.U.; Flynn, H.W., Jr; Smiddy, W.E.; Corey, R.P.; Miller, D. (2004). Endophthalmitis caused by Streptococcus pneumoniae. Am. J. Ophthalmol. 138 (2), 231-236.

14. Miragaia, M.; Thomas, J.C.; Couto, I.; Enright, M.C.; de Lencastre, H. (2007). Inferring a population structure for Staphylococcus epidermidis from multilocus sequence typing data. J. Bacteriol. 189 (6), 2540-2552.

15. Muyzer, G.; De Waal, E.C.; Uitterlinden A.G. (1993). Profiling of complex microbial populations by denaturing gradient gel electrophoresis analysis of polymerase chain reaction amplified genes coding for 16S rRNA. Appl. Environ. Microbiol. 59 (3), 695-700.

16. Navarro-Noya, Y.E.; Jan-Roblero, J.; González-Chávez, M.del C.; Hernández-Gama, R.; Hernández-Rodríguez， C. (2010). Bacterial communities associated with the rhizosphere of pioneer plants (Bahia xylopoda and Viguiera linearis) growing on heavy metals-contaminated soils. Antonie Van Leeuwenhoek. 97 (4), 335-349.

17. Okhravi, N.; Adamson, P.; Matheson, M.M.; Towler, H.M.; Lightman, S. (2000). PCR-RFLP mediated detection and speciation of bacterial species causing endophthalmitis. Invest. Ophthalmol. Vis. Sci. 41 (6), 1438-1447.

18. Park, I.H.; Park, S.; Hollingshead, S.K.; Nahm, M.H. (2007). Genetic basis for the new pneumococcal serotype, 6C. Infect. Immun. 75 (9), 4482-4489.

19. Peixoto, R.S.; da Costa-Coutinho, H.L.; Rumjanek, N.G.; Macrae, A.; Rosado, A.S. (2002). Use of rpoB and 16S rRNA genes to analyse bacterial diversity of a tropical soil using PCR and DGGE. Lett. Appl. Microbiol. 35 (4), 316-320-9.

20. Sanders, M.E.; Norcross, E.W.; Moore, Q.C.; Onwubiko, C.; King, L.B.; Fratkin, J.; Marquart, M.E. (2008). A comparison of pneumolysin activity and concentration in vitro and in vivo in a rabbit endophthalmitis model. Clin. Ophthalmol. 2 (4), 793-800.

21. Sanders, M.E.; Norcross, E.W.; Robertson, Z.M.; Moore, Q.C., $3^{\text {rd }}$ Fratkin, J.; Marquart, M.E. (2011). The Streptococcus pneumoniae capsule is required for full virulence in pneumococcal endophthalmitis. Invest. Ophthalmol. Vis. Sci. 52 (2), 865-872.

22. Schabereiter-Gurtner, C.; Maca, S.; Rölleke, S.; Nigl, K.; Lukas, J.; Hirschl, A.; Lubitz, W.; Barisani-Asenbauer, T. (2001). 16S rDNA-based 
identification of bacteria from conjunctival swabs by PCR and DGGE fingerprinting. Invest. Ophthalmol. Vis. Sci. 42 (6), 1164-1171.

23. Schabereiter-Gurtner, C.; Maca, S.; Kaminsky, S.; Rölleke, S.; Lubitz, W.; Barisani-Asenbauer, T. (2002). Investigation of an anaerobic microbial community associated with a corneal ulcer by denaturing gradient gel electrophoresis and 16S rDNA sequence analysis. Diagn. Microbiol. Infect. Dis.43 (3), 193-199.
24. Ueda, K.; Seki, T.; Kudo, T.; Yoshida, T; Kataoka, M. (1999). Two distinct mechanisms cause heterogeneity of 16S rRNA. J. Bacteriol. 181 (1), 78-82.

25. van Vliet, M.J.; Tissing, W.J.; de Bont, E.S.; Meessen, N.E.; Kamps, W.A.; Harmsen, H.J. (2009). Denaturing gradient gel electrophoresis of PCR-amplified gki genes: a new technique for tracking streptococci. $J$. Clin. Microbiol. 47 (7), 2181-2186. 